\title{
Experiential Learning: Learning through Reflective Practice
}

\author{
Karen Roland \\ University of Windsor, Canada
}

\begin{abstract}
Experiential learning is a means to enhance student learning by providing the opportunity, through reflective practice, for students to develop knowledge and apply theory in practice. Based on the extant literature, and my experience as an experiential learning specialist in a teacher education program, I offer the following as core benefits of experiential learning for students: 1) experiential learning provides students with opportunities to critically engage in learning providing students with a deeper and more meaningful understanding of theoretical knowledge beyond the textbook; 2) providing mentoring and guided navigation of the realities of the workplace the ability to successfully traverse the nuanced and at times, problematic realities of the workplace; and most importantly, 3) allowing for the development of a thoughtful, personal commitment to professionalism through reflective practice intrinsically, through reflective practice, students become agents of their own learning characterized by a meta-cognitive awareness of their development as novice professionals. Throughout this paper these benefits are discussed through the lens of three research studies: Conversations About Education, Associate Teacher Feedback, and Teacher Candidate Partnerships. This research context underscores the impact of experiential learning to engage students so that they may learn and grow professionally through reflective practice.
\end{abstract}

\section{Introduction}

University educators have come a long way in terms of their willingness to embrace the significance and relevance of experiential learning as a means to enhance student learning. Specifically, experiential learning provides students with the opportunity to demonstrate their ability to apply theory in practice through professional competence; this competence is underscored by critical analysis and self-reflection concerning their practice. Prior to my role as an experiential learning specialist I was a university cooperative education (co-op) coordinator. As a co-op coordinator I supervised and advised undergraduate students in a diverse range of academic disciplines during the co-operative education component of their degree programs. The value of co-op placements to provide these students with opportunities to apply theory-in-practice and to develop their professional practice during 'on the job' experience, became readily apparent to me. Today, as an experiential learning specialist in a Southwestern Ontario Faculty of Education preservice teacher education program, recognition of the positive impact of experiential learning as an approach with which to enhance student development of professionalism through reflective practice, has gained even greater relevance for me as an educator.

Professionalism in teaching practice is essential, and in most jurisdictions there are ethical and professional standards of practice that must be adhered to for licensing within the profession. However, while experiential learning may be crucial to successful entry into the teaching profession, I would suggest that this learning approach would also be highly beneficial to students pursuing post-secondary academic studies in any discipline. The reason is that experiential learning educates students to become agents of their own learning - in other words, to apply theoretical knowledge in practice, praxis.

John Dewey postulates that it is the responsibility of educators to recognize and be aware of the learning environments that are conducive to growth [3, p. 40], and that furthermore, "continuity and interaction in their active union with each other provide the measure of the educative significance and value of an experience" [3, p. 44-45]. From a post-secondary curriculum planning stance what this means for educators is that experiential learning must be thoughtfully planned to include curricula that interacts with experience, what is referred to in some teacher education programs as a constructivist pedagogical approach. However, Kolb [5] also adds that beyond a constructivism in which learning occurs solely in the mind of the learner, that "...learning is the process whereby knowledge is created through the transformation of experience. Knowledge results from the combination of grasping experience and transforming it" [5, p. 67]. 
These are important factors to consider as they emphasize the positive impact experiential learning may have in terms of student learning and engagement at the post-secondary academic level.

Experiential learning in post-secondary academic programs may take many forms, some examples include: co-op placements, practicum placements, and internships [7]. There are similarities as well as differences in each of these experiential learning models. For instance, co-op placements are usually paid work experience that weave throughout academic studies whereby a student is hired for a specified period of time by an employer - this may be project related work, or, it may be a regular position within the company. Practicum placements differ in that students in pre-service teacher education programs are not hired or paid as teachers during their practicum placements; and yet, in Ontario, these students once on placement, become affiliate members of the teacher unions. This means that student teachers are held to the ethical and professional standards of the teaching profession in Ontario [7]. An important similarity of both co-op and practicum experiential learning placements is that the student's academic program alternates or weaves between periods of academic study, and work experience placements. Additionally, during their work experience placements students are provided with an on-the-job mentor/supervisor as well as an academic supervisor to provide them with guidance and assessment. Internships on the other hand may occur in the middle or at the end of an academic program. Internships may also be paid or unpaid work experience placements whereby the student is afforded the opportunity to gain workrelated experience at the behest of the company/organization - it should be noted that recently some educators and employers have voiced their concern about the practice of unpaid internships as being unfair to students, particularly in terms of extended internships - internship placements may range from 4 to 12 months in length [7].

In discussing the role of employers to meet the needs of the labour market, the Conference Board of Canada [2] asserts that Canadian employers have an expectation that post-secondary institutions will produce 'job-ready' graduates with the skills and knowledge necessary to align with the needs of the employment marketplace. Furthermore, this alignment of graduates with labour market needs has implications at a national level - there is a link between the school system and national well-being in terms of beneficial social and economic factors. The importance of this linkage is emphasized in Hargreaves and Fullan's assertion that effective school systems are: "nation builders and national assets" [4, p. 2]. Therefore, I would suggest that experiential learning is of great importance for $21^{\text {st }}$ century teaching and learning. Based on the extant literature, my own experience as an experiential learning specialist and co-operative education coordinator, in this paper I will discuss what I suggest are three core benefits of experiential learning for students.

\section{Benefits of experiential learning}

The discussion in this paper is based on a presentation I made in 2016 at an international conference on education [7]. The following are what I would suggest are the core benefits of experiential learning for students: 1) experiential learning provides students with opportunities to critically engage in learning - providing students with a deeper and more meaningful understanding of theoretical knowledge beyond the textbook; 2) experiential learning provides students with mentorship and a guided navigation so that they may hone the skills necessary to successfully traverse the nuanced, and at times, problematic realities of the workplace; and most importantly, 3) experiential learning allows for the development of a thoughtful and personal commitment by students to professionalism through reflective practice intrinsically, through reflective practice, students become agents of their own learning characterized by a meta-cognitive awareness of their development as novice professionals [7]. In the remainder of this paper these three beneficial aspects of experiential learning will be discussed through the lens of research that I have conducted over the years in my role as an experiential learning specialist in a preservice teacher education program.

\subsection{Enhancing student engagement through reflective practice}

Kolb suggests that as a learning theory, experiential learning offers a "holistic integrative perspective on learning that combines experience, perception, cognition, and behavior [5, p. 31], what he opines are the four modes of the experiential learning cycle: "experiencing, reflecting, thinking, and acting" [5, p. 295]. Kolb further asserts that in experiential learning theory, reflection involves the "internal transformation of experience".... which requires reflective "cognitive complexity and the capacity for critical thinking" [5, p. 58]. He postulates that experiential learning spaces support a very different model of learning than the traditional classroom by offering students the opportunity to engage in deeper more meaningful learning. 
Furthermore, he expounds that experiential learning may result in greater learning retention as the student moves from one experiential learning mode to another throughout the learning cycle. Therefore, viewed from an experiential learning lens, developing and enhancing student engagement involves exploring ideas and reflecting on this learning process, as well as learning from others' experience and shifting points of view to create new knowledge and understanding [9].

Sharing knowledge and perspectives is a key element of developing professional practice. With this in mind, in 2012 working with two graduate research assistants, we conducted a program evaluation of a pilot project offered through the Faculty of Education entitled, Conversations About Education. The purpose of this pilot project was to provide an experiential learning opportunity for student teachers outside of their regular classroom learning space by bringing them together with members of the educational community (faculty, school teachers, administrators, and educators who identified themselves as Newcomers to Canada), to discuss educational issues. This pilot project sought to create a 'collective forum' where educational issues could be discussed through a multi-epistemic lens [9]. Personal perspectives concerning issues relevant to education and classrooms in Ontario were discussed; the sharing of these personal perspectives allowed for a meaningful understanding of the lived/life experience of the participants. The goal of these discussions was to promote communitybuilding, and through reflective practice, allow participants as professional educators, to collectively confront bias in teaching practice.

Three separate Conversations About Education events hosted by the Faculty of Education, were held over a four month period. The first event was entitled, 'Creating a Community in your Classroom' and was facilitated by a local school board Child and Youth Worker. The event participants included Faculty of Education students and faculty members, school board teachers and administrators, and newcomers to Canada who identified as educators. The presentation by the Child and Youth Worker was followed by small group discussions of the following questions: What is the most supportive approach to dealing with disengaged students? What is your personal philosophy of discipline? What are some of the impact factors (environmental or situational) that students bring with them to the classroom? How do staff contribute to this? Why is your relationship with your students your insurance policy when times are bad? The next event entitled, 'Permission to Disagree' was facilitated by the Director of Education from the Canadian Civil
Liberties. Participants included Faculty of Education students and faculty members. This event involved group discussions of various human rights cases facing the courts in Canada. In each of the cases discussed the participants were encouraged to arrive at a number of possible decisions - the goal was to avoid consensus - hence, the participants were given permission to disagree. Participants were asked about how many points of view they could defend, acknowledging that there was no 'correct' answer. The goal of this session was to promote discussion and disagreement in a respectful space. The final event was entitled, 'Restorative Justice in our Schools' and was facilitated by a local high school Vice-Principal. Participants of this event included, Faculty of Education students and faculty members, and school board teachers and administrators. The Vice-Principal presented an overview of Restorative Justice Practices in schools, and facilitated a whole group discussion of the following central question: What is your capacity to implement restorative practices at the school, classroom or community level?

At the core of this pilot project was the belief that educators, engaging in reflective practice may challenge hegemony and stereotypical attitudes to become 'agents of change' to promote and protect social justice and equity within an educational community of practice [9]. This project supported a critical pedagogical approach with which participants were able to reflect and "contest cultural hegemony in the classroom....from sharing knowledge and diverse perspectives to keep abreast of the everchanging cultural diversity in classrooms and the educational community" [9, p. 484]. Thus, this study demonstrated how a local community came together to share experiences and insights with one another from diverse backgrounds. Further, that teachers, educators and students bring to the classroom experiences and preconceptions based on their own lived/life experiences. This project allowed for the exploration and discussion of pre-conceived ideas through a multi-epistemic lens.

Results from the program evaluation indicated that this pilot project was successful in providing an experiential learning opportunity for education professionals. In completing the program evaluation of this pilot project, focus group sessions were held with the event participants. During these focus group sessions the participants indicated that at the events they were able to engage in meaningful learning and to share knowledge. Furthermore, in reflecting upon their own learning, these participants indicated that they had benefited greatly by engaging in this learning process to develop a deeper understanding 
and appreciation of the multi-epistemic perspectives and experiences shared by other educators [9].

\subsection{Navigating the realities of the workplace through reflective practice}

Clarke states that teaching "is the professional practice of engaging teachers in the construction of knowledge directly related to the area of study known as teaching" [1, p. 600]. The design of most teacher education programs has been set up to scaffold experiential learning: course-based learning is integrated with practica to provide the learning experiences with which students may apply theory in practice, praxis. In terms of professional practice, Schön contends that 'reflect-in-action' in a professional context such as teaching, requires that the practitioner reflects on their knowing [12, p. 6]. Moreover, Schön opines that importantly, during professional learning contexts such as reflective practicums, learners are provided the time necessary to reflect to "unlearn initial expectations, to master the practice, and to shift repeatedly back and forth between reflection on and in action" [12, p. 9]; what he suggests is that learners become "proficient at a kind of reflection-in-action" [12, p. 8]. Schön's knowing-in-practice concept is particularly relevant to teacher education programs where experiential learning is facilitated through the mentorship and coaching provided by associate teachers in the classroom. These associate teacher mentor/coaches assist students to successfully navigate the nuanced and at times, problematic realities of the classroom [7].

Associate teachers play an extremely important role in the triumvirate teacher education learning partnership consisting of: student teacher, faculty advisor and associate teacher. The Faculty of Education values the opportunity to actively collaborate and consult with associate teachers as teacher educator colleagues. The construction of knowledge gained through the process of mentorship and guidance provided by associate teachers during practicum experiences is critically important to the development of student teachers' self-efficacy in teaching practice [8]. Furthermore, Osterman [6] elucidates that reflective practice, through an experiential learning process that integrates reflection with constructed knowledge, may foster this self-efficacy. Given this, in 2008 I conducted a study with associate teachers.

During 2008, 947 associate teachers employed with three Southwestern Ontario school boards were invited to voluntarily participate in a research study by responding to an online questionnaire, Associate Teacher Feedback: Anonymous \& Confidential
Questionnaire [8]. There were 134 associate teacher respondents to the online anonymous and confidential questionnaire. This questionnaire explored, from the perspective of associate teachers, the nature of the relationship between the associate teacher, the faculty advisor, and the teacher candidate (student teacher) [8]. The research study sought to identify strategies and recommendations with which to strengthen and foster the learningrelationship developed between these stakeholders. The questionnaire was comprised of three sections used to explore associate teachers' perceptions of: 1) their role as teaching mentors/coaches; 2) the support that they felt they required from faculty advisors to effectively perform their role as mentor/coach; and, 3 ) the recommendations that they could provide concerning strategies with which to strengthen the triumvirate learning partnership. [8]. At the crux of this study was an investigation to understand the role of associate teachers in facilitating experiential learning.

The online anonymous and confidential questionnaire used in the study was developed based on a review of extant literature. Question styles included: open-ended questions which invited associate teachers to share their individual insights; rank order questions which asked associate teachers to rank factors in terms of their importance for support; and lastly, associate teachers were asked to respond to a 5-point Likert scale indicating their level of agreement/disagreement with a question [8, p. 40].

The findings of the study indicated that associate teachers felt they needed greater opportunities to consult and collaborate with faculty, to engage in what Roth and Boyd [11] refer to as 'coparticipation in practice' in order to foster competency in the teaching-learning environment and to support "a mentoring model of consultation and collaboration in teacher education" [8, p. 42]. The associate teacher respondents characterized the faculty advisor as a partner "to support [the] teacher candidate and associate teacher; to advise and counsel [8, p. 40], and that the triumvirate partnership should involve "faculty advisors collaborating with associate teachers to clarify the goals of the pre-service [teacher education] program" [8, p. 42]. This point was illustrated further in terms of associate teachers expressed need to collaborate with faculty advisors in the assessment of each teacher candidate's progress. This was clearly noted in the following associate teacher's response, "My expectations are that the faculty advisor is there to advise and evaluate the candidate based on the candidate's performance with respect to what they have been taught at the faculty" $[8, \mathrm{p} .42]$. 
In ranking the support that faculty advisors could provide them as associate teachers, and to help them succeed in their role as mentor/coaches, associate teachers ranked the availability of the faculty advisor for consultation, particularly when teacher candidates are struggling in the classroom, as being one of the most important factors. This is evident in the following associate teachers' responses:

They [faculty advisor] need to be the middle 'person.' They need to know what the faculty expects and the associate teacher expects, and if for some reason the candidate isn't getting that picture, the advisor needs to make it clear to them. I feel that the advisor needs to be close at hand to each associate teacher [8, p. 41].

And, the following associate teacher response also confirms the need for the faculty advisor to be available:

To observe a student teacher on behalf of the university, to be another set of eyes on the student teacher's progress besides the associate, to offer advice to both the associate and student, to give the university's perspective on the classroom [8, p. 40].

Another factor ranked as one of the most important in terms of faculty advisors being supportive to associate teachers, was for the Faculty of Education to ensure that teacher candidates are "prepared and knowledgeable concerning the need for professionalism both in the classroom, and in the school community" [8, p. 43]. Associate teachers also stressed that stronger relationships between themselves and university faculty, facilitated by coteaching opportunities, may in fact foster what Roth and Boyd [11] assert is the theory-to-practice connection for student teachers. This connection of theory-to-practice has great significance in terms of learning to navigate the realities of the classroom, highlighting the interdependence of these partners as co-learners and collaborators in this experiential learning space - the practicum placement [7]. The study findings noted that the, "connection and integration of theory and practice in teacher education may be facilitated by sharing ideas and insights through the development of a community of practice with members of the triumvirate relationship" [8, p. 44].

\subsection{Developing professionalism through reflective practice}

Hargreaves and Fullan [4] assert that teachers must intrinsically develop a sense of professionalism to uphold the professional and ethical standards of the teaching profession, and, they must also comport themselves as professionals to gain the trust of the public. Osterman further opines that reflective practice may in fact foster professional growth, in her assertion that:

Reflective practice redefines both the concept of learning, and the role of the learner in the learning process. By emphasizing the importance of both personal experience and ideas, reflective practice establishes the importance of theory, but counsels against the study of theory in isolation from practice. Recognizing that the search for knowledge begins with experience and that no learning takes place unless the learner is both involved in and transformed by the learning process, reflective practice also emphasizes that the practitioner is central to the learning process [6, p. 142].

In their definition of professional capital Hargreaves and Fullan suggest that human capital (having the required knowledge and skills of a profession), is dependent on social capital (the ability to create and transfer knowledge in communities) [4, p. 3]. Furthermore these authors contend that "learning is the work, and social capital is the fuel; if social capital is weak, everything else is destined to failure" [4, p. 92]. The interdependency of human and social capital is particularly noteworthy in terms of teacher training and the Professional Learning Community (PLC) context. Further, these authors state that "teachers need to be professional (upholding high standards of ethical conduct), as well as perceived to be professionals (how teachers are perceived, a sense of public trust)" [4, p.86]. Their definition of professional capital includes both professional capacity, as well as effectiveness as an educator. These authors suggest that this professional capital has a significance and value in terms of the ability of our schools to create "...a high-performing school system, a competitive economy, and a cohesive society" [4, p. 79]. Given this, over the past several years, working with three school teachers, we facilitated a longitudinal research study entitled, Teacher Candidate Partnerships. In this study, student teachers were provided with the opportunity to voluntarily participate in Professional Learning Community (PLC) meetings facilitated by teachermentors. The aim of the study was to investigate the 
impact participation in these PLC meetings had on students' development of a professional identity, their ability to critically reflect, and the growth of their knowledge and implementation of researchbased practices in teaching [10]. Specifically, we were interested in knowing the effect that this collaborative and reflective experiential learning model, within a PLC context, would have in terms of building professional capital through the development of teaching partnerships.

A qualitative ethnographic methodology was used to collect data through participant-observation to explore the professional learning community experience both with the students (teacher candidates) enrolled in the pre-service teacher education program, as well as the teacher-mentors as researcher participants. These teacher-mentors were active participant-observers in the PLC throughout the study, and as such co-learners [10].

A key focus of this study was to investigate and challenge the traditional pre-service teacher education mentoring model; to move this mentoring model from an evaluative hierarchical stance, to a mentoring model that was collaborative and reflective in practice, and supported by the Professional Learning Community context [10]. The results of the Teacher Candidate Partnerships study suggest that the PLC mentorship model may be used as an effective learning-partnership strategy with which to build professional capital. The results of the study suggested that in fact the PLC experiential learning model was successful in creating a safe and collaborative learning space. Of particular importance was the positive impact noted that the shift from a hierarchical evaluative mentoring model (a teacher-mentor supervising and evaluating a student teacher), to one that was collaborative and reflective, had in terms developing a teachingpartnership which included all participants as colearners. Additionally, in the findings it was noted that students (teacher candidates) felt a greater awareness of their professional identity as teachers, along with increased growth in their ability to critically reflect and consider the perspectives of their colleagues [10]. The students also reflected and shared that they felt the mentoring they received from the teacher-mentors in the study was highly effective in development of their sense of selfefficacy in teaching practice [10]. The findings of this study support the Professional Learning Community as an example of an experiential learning model that fosters the development of an intrinsic awareness of professionalism developed through reflective practice; as co-learners in this partnership, students became agents of their own learning and development as novice professionals [7].

\section{Conclusion}

In conclusion, the research studies I have discussed in this paper provide a contextualization of what I have identified as three core benefits of experiential learning, learning through reflective practice: 1) enhancing student engagement; 2) providing opportunities to learn the skills necessary to effectively navigate the realities of the workplace; and, 3) providing opportunities for students to develop a personal commitment to professionalism through reflective practice. Osterman, in speaking about the impact of reflective practice in schools, suggests that there must be an emphasis on the importance of theory and ideas, as well as emphasis on the importance of experience and reflection:

....reflective practice challenges educators to become personally and actively involved in the creation of better schools. It challenges them to examine the ideas which shape schools and to actively engage in reconstructing that reality. Without restructuring the underlying mindscapes restructuring of schools will not occur [6, p. 151].

The program evaluation of the community-based experiential learning pilot project, Conversations About Education, found that the project supported an experiential learning approach during which educators from diverse backgrounds and lived/life experiences were able to share knowledge and perspectives to engage in deeper learning. The participants in the program evaluation "reported that engagement in the pilot program events as members of a 'collective forum' to discuss educational issues, allowed them to nurture and develop a deeper understanding and respect for alternate viewpoints" [9, p. 23]. Furthermore, through reflection on their learning, participants were able to gain a greater understanding and appreciation of the multiepistemic perspectives and experiences shared by other educators. In terms of professional development, the program evaluation participants also shared that as educators, they believe that "they have an obligation to promote social justice and equity in schools" [9, p.23]. This finding was clearly evident through the thoughtful and insightful engagement of these participants and their willingness to critically reflect on not only on their own individual views, but also in those shared by other educators. Therefore, the stated goals of the Conversations About Education experiential learning pilot program appeared to have been met in terms of:

1) relationship building to create a 'knowledge community' in which educational issues were 
examined through a multi-epistemic lens; and, 2) also providing professional development opportunities for teaching professionals focused on social justice issues and the implications of lived/life experience on confronting bias in the teaching profession" [9, p. 25].

The findings from the study, Associate Teacher Feedback indicated that the associate teacher participants fully understood the importance of their role as mentor and guide for student teachers to effectively navigate the realities of the classroom. In highlighting the interdependence of the members of the triumvirate experiential learning partnership, and the importance of strengthening the theory-topractice connection for student teachers, associate teachers articulated a need for more opportunities to collaborate with faculty in the teacher education program. Furthermore, the triumvirate members, operating as members of a community of practice during an experiential learning field experience, may in fact provide a learning opportunity with which to encourage reflective practice. Development of communities of practice within experiential learning field placements may work to foster "active consultation and collaboration between the associate teacher and the faculty advisor as a representative of the university, and between the associate teacher and the teacher candidate as the future generation of the teaching profession" [8, p. 45]. I would suggest that faculty advisors play a pivotal role in strengthening the triumvirate relationship, and that they may effectively do so through the encouragement of reflective practice amongst all the members of this experiential learning partnership. "This [triumvirate] relationship may yield benefits not only for the future of the teaching profession, but also for the educational system through the creation of a learning environment which actively and critically examines what constitutes effective and professional teaching practice" [8, p. 45].

The Teacher Candidate Partnerships study articulated the effectiveness of Professional Learning Communities as an experiential learning model. The student (teacher candidate) participants reported their development of a deeper and nuanced understanding and appreciation of the "complexity of the practice of teaching, and therefore the need for a collaborative and self-reflective learning stance on their part" ....additionally, these students reported an increase in terms of a "sense of self-efficacy in developing a personal philosophy of teaching that clearly articulated what makes them a teacher" $[10$, p.238]. And further, this led to the participants acknowledgement for "the need for life-long learning and continued professional development" [10, p. 238]. They indicated that the partnership they had experienced with teacher-mentors in the professional learning community underscored their understanding of the collaborative nature of teaching and the social responsibility of the profession - teachers have an enormous responsibility to their students, the caregivers of those students, the community, and society as a whole. Participants shared that the Professional Learning Community meetings provided them with the opportunity to develop a personal commitment to professionalism through reflective practice. Intrinsically, through reflective practice, these students became agents of their own learning and development as novice professionals. Given that:

"schools are societal transmitters of knowledge and skills, it is imperative that teachers have the professional capacity to be astute learners to effectively teach the 21 st century skills required by classroom students. Professional Learning Communities may provide a learner-centered environment with which to explore professional issues, questions, and knowledge, and thereby build professional capital through the development of teaching partnerships" [10, p. 238].

Finally, Dewey's philosophy of experience and education holds true in that education, to accomplish its purpose must be based on the life experience of the individual [3]. As such, I would suggest that experiential learning may be used as an effective pedagogical model for students to learn through reflective practice. This aligns well with the mission of the university today to encourage students to embrace the concept of life-long learning, and further to prepare graduates to not only think well and to critically reflect on their learning, but also for these graduates to develop the professionalism required in the workplace [7].

\section{References}

[1] A. Clarke, "The Recent Landscape of Teacher Education: Critical Points and Possible Conjectures", Teaching and Teacher Education, 17(5), Elsevier, 2001, pp. 599-611.

[2] Conference Board of Canada. "Developing Skills: Where are Canada's Employers?" Accessed July 11, 2017, http://www.conferenceboard.ca/topics/education/comment aries/14-03 20/developing_skills_where_are_canada_s_em ployers.aspx\#ftn1-ref (Access date: 2 September, 2016)

[3] Dewey, J. Experience and Education, Collier, New York, 1938.

[4] Hargreaves, A. and M. Fullan, Professional Capital: Transforming Teaching in Every School, Continuum International Publishing Group, New York, 2012. 
[5] Kolb, D. A., Experiential Learning: Experience as the Source of Learning and Development $\left(2^{\text {nd }}\right.$ Edition), Pearson Education, Inc., New Jersey, New York, 2015.

[6] K.F. Osterman, "Reflective Practice: A New Agenda for Education", Education and Urban Society, 22(2), SAGE, 1990, pp. 133-152.

[7] K. Roland, "Experiential Learning: Developing Professionalism through Reflective Practice", Conference proceedings of the World Congress on Education: Global Issues in Education and Research, 2016, Dublin, Ireland.

[8] K. Roland, "Associate Teacher Perspectives of the Triumvirate Relationship in Teacher Education: The Role of Faculty Advisors", Brock Education Journal, 19(2), University of Brock, Faculty of Education, pp. 36-47.

[9] K. Roland, J. Colella and B. Igbokwe, "Conversations about Education: Professional Development through a Multi-epistemic Lens", Teachers and Teaching: Theory and Practice, 20(4), Taylor \& Francis Online, 2014, pp.483-498.

[10] K. Roland, S. Johnson, L. Jones and C. Boyer, "Building Professional Capital Through the Development of Teaching Partnerships", Conference proceedings of the 8th European Conference on Intellectual Capital, Academic Conferences and Publishing International Limited, Ca' Foscari University of Venice, Italy, 2016, pp. 231-239.

[11] W.M. Roth, and N. Boyd, "Coteaching, as Colearning, is Praxis", Research in Science Education, 29(1), Springer, 1999, pp. 51-67.

[12] D. A. Schön, “A Symposium on Schön's Concept of Reflective Practice: Critiques, Commentaries, Illustrations", Journal of Curriculum and Supervision, 5(1), ASCD, 1989, pp. 6-9. 